\section{Some Lichen Products Have Antimicrobial Activity}

J. Garcia Rowe ${ }^{\mathrm{a}}$, M. D. Garcia Gimenez ${ }^{\mathrm{b} *}$ and M. T. Saenz Rodriguez ${ }^{\mathrm{b}}$

a Laboratory of Vegetal Biology, Faculty of Pharmacy, University of Seville, Spain

b Laboratory of Pharmacognosy, Faculty of Pharmacy, University of Seville, Spain. Fax: 07 34(9) 54233765. E-mail: gimenez@fafar.us.es

* Author for correspondence and reprint requests

Z. Naturforsch. 54c, 605-609 (1999);

received February 8/April 16, 1999

Lichens, Antimicrobial Activity, Lichen Products

Antimicrobial activity in some lichens from south Spain has been studied. Some lichenical substances are also identified. The structures of all compounds were elucidated by physical, spectral and chemical methods. A very high activity against Gram-positive bacteria has been observed in lichens containing usnic acid.

\section{Introduction}

Lichen is a symbiotic association of a higher fungus (mycobiont) and a photosynthetic partner (photobiont). Normally, in our zone the fungal symbiont is an ascomycete and the photosynthetic symbiont may be a eukaryotic green alga and/or a cyanobacterium. These organisms synthesize several compounds (lichen substances) with an important role as antibiotic products.

In recent years, many investigations have been carried out on lichen substances and their antimicrobial properties. The great majority of these have been conducted on para- and meta-depsides, depsidones, benzyl esters, dibenzofurans and phenolic and aliphatic acids. In this line of research, we have already published work on antimicrobial activity and identification of lichen substances (Rowe et al., 1989; Rowe et al., 1991).

Lichens synthesize the above-mentioned substances by a general process very similar to fatty acid synthesis, that is to say, by successive condensations of acetate units. In the case of non-lichenized fungi, orsellinic acid undergoes a decarboxylation to orcinol starting from which the characteristic compounds of these fungi would be synthesized. In the case of lichens (lichenized fungi) (Ark,1960), it is thought that an inhibitor of decarboxylase, synthesized by the photobiont, reaches the mycobiont where it produces its inhibitor effect: because the substances formed starting from orsellinic acid are characteristic and exclusive, with few exceptions, in the lichen symbiosis. The formation of these cyclic substances with free $-\mathrm{OH}$ radicals, generally toxic for most living creatures, can be due to a response to external attacks (Ahmadjian, 1967)). We have also suggested that when the above-mentioned compounds are accumulated on mycobiont hyphae, this would influence the permeability of the algal cellular wall, allowing food transfer towards the fungi. However, the accepted idea in relation to these substances is based on their antimicrobial activity against GRAM+ bacteria and other organisms, notably moulds and some viruses (Bustinza, 1951a, 1951b). Usnic acid, the active compound of most of them, is used to treat dermatosis and infected burns. It was interesting for us to specify the spectrum of antibiotic activity in some lichens.

\section{Materials and Methods}

\section{Plant material}

Eleven lichen species have been studied because of either their abundance (Parmeliella plumbea, Coelocaulon aculeatum, Usnea rubicunda, Parmelia tinctina and Ochrolechia parella) or their taxonomic interest (Pertusaria albescens, Ochrolechia parella and Pertusaria pseudocorallina), or because cyanobacteria comprise the photobiont (Parmeliella plumbea, Nephroma laevigatum and Collema spp.), or as comparison material with other species whose genera were previously studied (Usnea rubicunda and Physconia venusta).

Most species have been collected in Cádiz province some of them in the Sierra de Grazalema Natural Park, surroundings whose climatic characteristics have been described before (Rowe et al., 1989). Others were collected in the Los Alcornocales Natural Park (with a similar climate, although the average levels of edaphic humidity are higher), and the remainder were from a locality in Málaga province (near to both Parks so similar in climatic characteristics) or from Huelva province (in particular, those species from coastal sands of Doñana National Park. 
A mediterranean climate with a very dry summer season is typical in all localities where the lichens grow.

Next taxa have been collected:
Pertusaria albescens (Huds.) M. Choisy and Werner

Locality: Cadiz, Alcala de los Gazules, Puerto Galiz (February 11, 1993).

Table I. Compounds identified from different lichens.

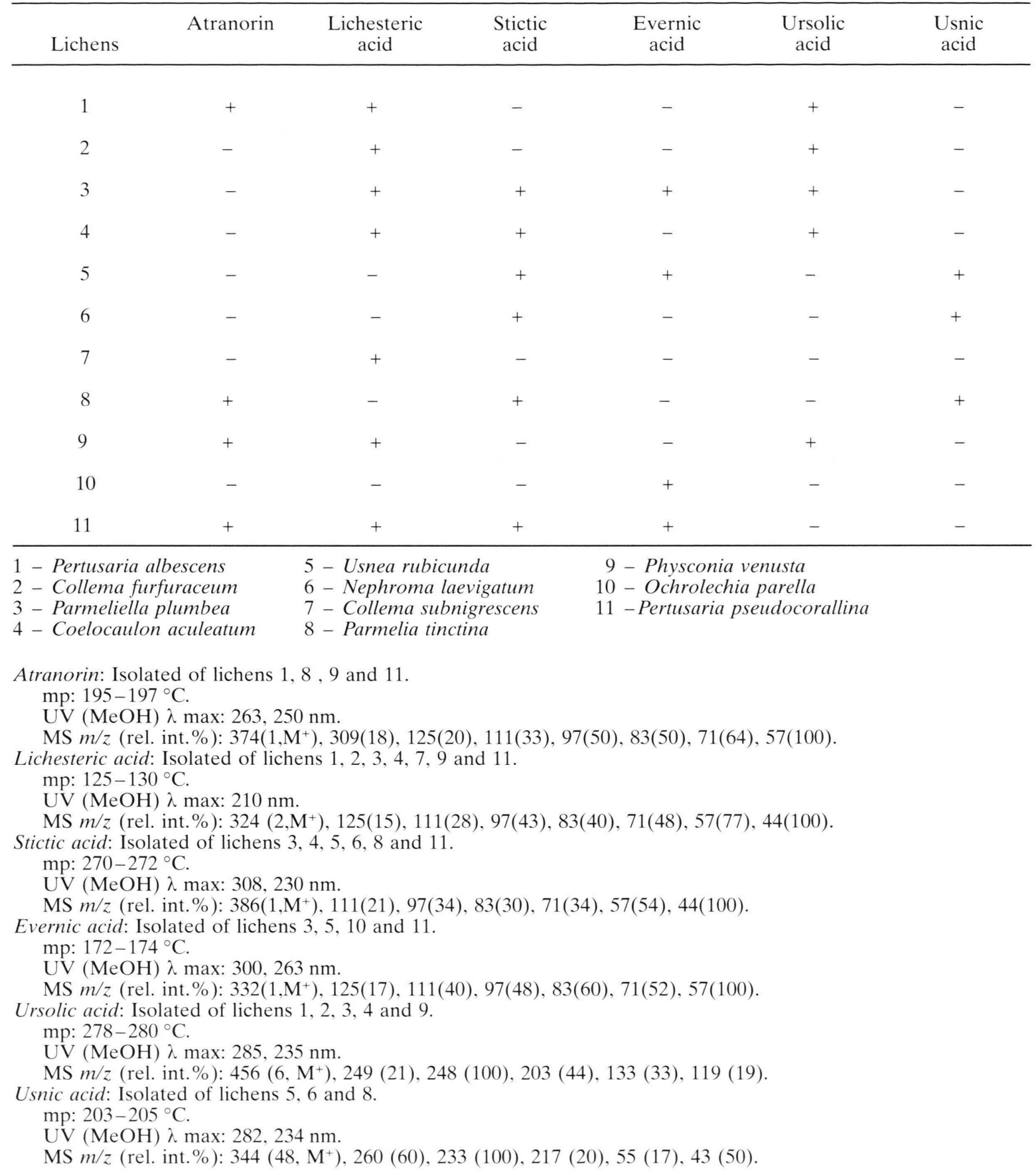


In the middle of trunks and old branches of Quercus rotundifolia Lam. and Quercus faginea Lam. forming large thalli. Rarely on Quercus suber L.. Always on facing north.

Collema furfuraceum (Arn.) DR. em. Degel.

Locality: Cadiz, Alcala de los Gazules, Puerto

Galiz (February 11, 1993).

With the same ecology as $C$. subnigrescens.

Parmeliella plumbea (Lightf.) Müll. Arg.

Locality: Cadiz, Alcala de los Gazules, Puerto Galiz (February 11, 1993).

In the middle of trunks and old branches of Quercus rotundifolia Lam. and Quercus faginea Lam. Rarely on Quercus suber L.

Coelocaulon aculeatum (Schreber) Link

Locality: Huelva, Doñana National Park, Biological Reserve, Sabinar del Tio Pulga (July 2, 1992).

Either on small shrubs bases or coastal sands, being in this case a wandering species.

Usnea rubicunda Stirton

Locality: Cádiz, Ubrique, La Ventalleja (October 15, 1993).

Throughout the trunk of Quercus suber L. and Quercus rotundifolia Lam. Also found on old branches. Very rare on acid rocks.

Nephroma laevigatum Ach.

Locality: Cádiz, Ubrique, La Ventalleja (October 15, 1993).

On middle zone trunk of Quercus suber L., Quercus faginea Lam. or Quercus rotundifolia Lam. Commonly on acid rocks, always between small cushions of bryophytes.

Collema subnigrescens Degel.

Locality: Cadiz, Ubrique, La Ventalleja (October 15, 1993).

In the middle of trunks and old branches of Quercus rotundifolia Lam. and Quercus faginea Lam. Rarely on Quercus suber L., particularly facing north.

Parmelia tinctina Maheu \& A. Gillet

Locality: Malaga, Cortes de la Frontera, La Sauceda (February 19, 1993).

On nitrophilous surfaces of acid rocks well exposed to sun and rainfall.

Physconia venusta (Ach.) Poelt

Locality: Malaga, Cortes de la Frontera, La Sauceda (February 19, 1993).

In the middle of trunks and old branches of Quercus rotundifolia Lam. and Quercus suber L.
Ochrolechia parella (L.) Massal.

Locality: Malaga, Cortes de la Frontera, La Sauceda (February 19, 1993).

On nitrophilous surfaces of acid rocks more or less exposed to sun and rainfall.

Pertusaria pseudocorallina (Liljeblad) Arnold

Locality: Malaga, Cortes de la Frontera, La Sauceda (February 19, 1993).

On slightly nitrophilous surfaces, more or less sloping, of acid rocks, with little or no exposure to the sun, but exposed to rainfall. Almost always facing north.

\section{Extraction and identification of lichen substances}

The lichens $(100 \mathrm{~g})$ were powdered in a mortar and soaked overnight in acetone $(10 \mathrm{ml})$ at $25^{\circ} \mathrm{C}$. The extracts were concentrated under reduced pressure, and $1 \mathrm{~g}$ of dry residue in each case was passed through a column packed with silica gel using $n$-hexane, $n$-hexane/ethyl ether $(8: 2,5: 5,2: 8$ $\mathrm{v} / \mathrm{v})$, ethyl ether, ehtyl ether/acetone (8:2, 5:5, 2:8 v/ v) and acetone as eluants depending on the polarity of the compounds.

The lichen substances were isolated by precipitation or preparative thin layer chromatography.

The different compounds were identified by thin layer chromatography (TLC) according to the standarized methods for lichen products (Culberson, 1970, 1972, 1974, 1982), spectroscopy techniques UV (Perkin-Elmer Lambda 3 spectrophotometer), mass spectra (Kratos MS 80 RFA using a direct inlet system at $70 \mathrm{eV}$.) and melting point (Microscope Thermovar HT1B11 Reichert-Jung). (See Table I).

\section{Test of antimicrobial activity}

The qualitative antimicrobial assay of acetone extracts ( $1 \mathrm{mg}$ dry residue/ml) was carried out by the disc-diffusion method (Bauer et al., 1966).

The zones of growth inhibition around sterile discs of Whatman $n^{\circ} 3$ paper with a diameter of $5.5 \mathrm{~mm}$ were measured after $24 \mathrm{~h}$ of incubation at $37^{\circ} \mathrm{C}$. The discs contained increasing amounts of samples to be assayed $(15,25$ and $50 \mu \mathrm{l})$.

All the tests were conducted in triplicate and average results have been recorded.

The test organisms were Bacillus megaterium (ATCC 33085), Bacillus cereus (ATCC 14579), Staphylococcus aureus (ATCC 25923), Escherichia 
Table II. Antibacterial activity of different lichens of southern Spain. Diameter of the inhibition zone in mm.

\begin{tabular}{|c|c|c|c|c|c|c|c|c|c|c|c|c|}
\hline & Doses & 1 & 2 & 3 & 4 & 5 & 6 & 7 & 8 & 9 & 10 & $11 *)$ \\
\hline $\begin{array}{l}\text { B.mega- } \\
\text { terium }\end{array}$ & $\begin{array}{l}15 \text { ul } \\
25 \text { ul } \\
50 \mathrm{ul}\end{array}$ & $\begin{array}{c}9 \\
10 \\
11,5\end{array}$ & $\begin{array}{l}- \\
- \\
-\end{array}$ & $\begin{array}{l}- \\
- \\
-\end{array}$ & $\begin{array}{l}9 \\
11,5 \\
14\end{array}$ & $\begin{array}{l}13 \\
15 \\
17\end{array}$ & $\begin{array}{l}10 \\
11 \\
12\end{array}$ & $\begin{array}{l}- \\
- \\
-\end{array}$ & $\begin{array}{l}12 \\
14 \\
14,5\end{array}$ & $\begin{array}{l}- \\
6 \\
7\end{array}$ & $\begin{array}{l}6 \\
7 \\
8,5\end{array}$ & $\begin{array}{l}- \\
6 \\
6,5\end{array}$ \\
\hline $\begin{array}{l}B . \\
\text { cereus }\end{array}$ & $\begin{array}{l}15 \mathrm{ul} \\
25 \mathrm{ul} \\
50 \mathrm{ul}\end{array}$ & $\begin{array}{c}9 \\
9,5 \\
11\end{array}$ & $\begin{array}{l}- \\
-\end{array}$ & $\begin{array}{l}- \\
- \\
-\end{array}$ & $\begin{array}{l}9,5 \\
12 \\
15\end{array}$ & $\begin{array}{l}13 \\
15,5 \\
18\end{array}$ & $\begin{array}{l}9,5 \\
11 \\
12\end{array}$ & $\begin{array}{l}- \\
- \\
-\end{array}$ & $\begin{array}{l}12,5 \\
14 \\
15\end{array}$ & $\begin{array}{l}6 \\
6,5 \\
7,5\end{array}$ & $\begin{array}{l}6,5 \\
7,5 \\
9\end{array}$ & $\begin{array}{l}- \\
\overline{6}\end{array}$ \\
\hline $\begin{array}{l}\text { S. } \\
\text { aureus }\end{array}$ & $\begin{array}{l}15 \mathrm{ul} \\
25 \mathrm{ul} \\
50 \mathrm{ul}\end{array}$ & $\begin{array}{l}6 \\
6 \\
7\end{array}$ & $\begin{array}{l}- \\
- \\
-\end{array}$ & $\begin{array}{r}7 \\
9 \\
11\end{array}$ & $\begin{array}{c}7 \\
7 \\
10,5\end{array}$ & $\begin{array}{l}18 \\
22 \\
27\end{array}$ & $\begin{array}{l}13 \\
18 \\
23\end{array}$ & $\begin{array}{l}6 \\
6,5 \\
6,5\end{array}$ & $\begin{array}{l}20 \\
26 \\
32\end{array}$ & $\begin{array}{l}6 \\
6 \\
7\end{array}$ & $\begin{array}{r}8 \\
10 \\
13\end{array}$ & $\begin{array}{l}6 \\
6,5 \\
6,5\end{array}$ \\
\hline
\end{tabular}

\begin{tabular}{llllllllllll} 
E. & $15 \mathrm{ul}$ & 8 & - & 6 & - & 6 & - & - & 6 & - & - \\
coli & $25 \mathrm{ul}$ & 12,5 & - & 11,5 & - & 7 & - & - & 7 & - & - \\
& $50 \mathrm{ul}$ & 15 & - & 14 & - & 7,5 & - & - & 7,5 & - & - \\
\hline
\end{tabular}

\begin{tabular}{|c|c|c|c|c|c|c|c|c|c|c|c|c|}
\hline \multirow{3}{*}{$\begin{array}{l}\text { P.aeru- } \\
\text { ginosa }\end{array}$} & $15 \mathrm{ul}$ & - & - & - & - & - & - & - & - & - & - & - \\
\hline & $25 \mathrm{ul}$ & - & - & - & - & - & - & - & - & - & - & - \\
\hline & $50 \mathrm{ul}$ & - & - & - & - & - & - & - & - & - & - & - \\
\hline \multirow{3}{*}{$\begin{array}{l}\text { S. typhy- } \\
\text { murium }\end{array}$} & $15 \mathrm{ul}$ & - & - & - & - & 3 & - & - & 6 & - & - & - \\
\hline & $25 \mathrm{ul}$ & - & - & - & - & 9 & - & - & 7 & - & - & - \\
\hline & $50 \mathrm{ul}$ & - & - & - & - & 13 & - & - & 7 & - & - & - \\
\hline
\end{tabular}

*) 1 - Pertusaria albescens; 2 - Collema furfuraceum; 3 - Parmeliella plumbea; 4 - Coelocaulon aculeatum; 5 Usnea rubicunda; 6 - Nephroma laevigatum; 7 - Collema subnigrescens; 8 - Parmelia tinctina; 9 - Physconia venusta; 10 - Ochrolechia parella; 11 - Pertusaria pseudocorallina.

coli (CCM 180), Pseudomonas aeruginosa (ATCC 27853) and Salmonella typhimurium (ATCC 14028).

\section{Results and Discussion}

The compounds identified in the different lichens are summarized in Table I.

The data obtained in the qualitative antimicrobial assay are presented in Table II.

From the assayed lichens, the three species enriched in usnic acid (U. rubicunda, N. laevigatum and $P$. tinctina) are the most active species, mostly against the Gram-positive bacteria. This bacterici- dal action has been demonstrated previously in lichens rich in usnic acid (Bustinza et al., 1951; Bargellini et al., 1946).

Moreover, U. rubicunda and P. tinctina have shown an inhibition effect against some Gramnegative bacteria (E. coli and S. typhimurium). This activity might be due to the lichenic phenolic substances that have been found in these two species. In previous reports, we also demonstrated the antibacterial effect of $P$. caperata and Usnea spp. against Gram-negative bacteria: P. vulgaris, E. coli and S. marcescens.

The tested Collema species (C. furfuraceum and C. subnigrescens) have shown no action against any of the assayed microorganisms. 
Ahmadjian V. (1967), The Lichens Symbiosis. Blaisdell Pub. Co., Waltham, Mass. USA.

Ark P. A., Bottini A. T. and Thompson J. P. (1960), Sodium usnate as an antibiotic for plants diseases. Plant. Dis. Reporter 44, 200-202.

Bargellini G., Del Pianto E. and Marini-Bettolo G. B. (1946), Atti della Accademia Nazionale dei Lincei I. 12, $1252-1254$.

Bauer A. W., Kirby W. M. M., Scherris JK. C. and Turck M. (1966), Antibiotic susceptibility testing by a standarized single isc method. Am. J. Clin. Pathol. 45, $493-496$.

Bustinza F. (1951a), A note on the antibacterial activity of Cladonia rangiferina Web., C.sylvatica (L.) Hoff. Emend. Sandst, and $C$. impexa Harm. Antibiot. Chemother. 1,443-446.

Bustinza F. (1951 b), Acido usnico : su acción sobre bacterias $\mathrm{g}(+)$. Endeavour 10, 95-98.

Culberson C. F. and Kristinsson H. (1970), Improved conditions and new data for the identification of lichen products by a standardized thin-layer chromatographic method. J. Chromatogr. 46, 85-93.
Culberson C. F. (1972), Improved conditions and new data for the identification of lichen products by a standarized thin layer chromatografic .J. Chromatogr. 72, 113-125.

Culberson C. F. (1974), Conditions for the use of Merck silica gel 60 F254 plates in the standardized thin-layer chromatographic technique for lichen products. J. Chromatogr. 97, 107-108.

Culberson C. F. and Johnson A. (1982), Substitution of methyl tert-butyl ether for diethyl ether in the standardized thin-layer chromatographic method for lichen products. J. Chromatogr. 238, 483-492.

Rowe J. G., Saenz M. T. and Garcia M. D. (1989), Contribution â l'étude de l' activité antibactérienne de quelques lichens du sud de l' Espagne. Ann. Pharm. Fr. 47, 89-94.

Rowe J. G., Saenz M. T., Garcia M. D. and Gil A. M. (1991), Nouvelle contibution à l' étude de l'activité antimicrobienne et identification des substances lichèniques de quelques lichens du sud de l'Espagne. Ann. Pharm. Fr. 49, 278-285. 